Bull. Fac. Agric., Cairo Univ., 69: 201-210.(2018).

\title{
GROWTH STUDY OF SOME LOCAL AND EXOTIC TIMBER TREE SPECIES IRRIGATED WITH TREATED WASTE WATER
}

(Received:19.8.2018)

\author{
By \\ M. I. Bahnasy \\ Forestry and Timber Trees Department, Horticultural Research Institute, \\ Agricultural Research Center, Giza, Egypt.
}

\begin{abstract}
This study was carried out in the Serapium Forest Plantation, Ismailia Governorate, Egypt during 2015-2018 seasons to study the response of certain tree species to treated waste water. The tree species that have been tested are Khaya senegalensis, Swietenia mahagoni, Azadirachta indica, Tectona grandis, Pongamia pinnata, Casuarina equisetifolia, Gmelina arborea and Corymbia citriodora. After three years of planting, the tallest plants were $C$. citriodora, followed by $C$. equisetifolia and Gmelina arborea. However, the highest increment in the diameter of trees was in $C$. citriodora, followed by $G$. arborea and $C$. equisetifolia in the first ranking. While, the smallest increase in number of branches was in $C$. citriodora as compared to the other tested species. The highest specific gravity value of wood was in $C$. citriodora followed by $P$. pinnata. For the fiber length, $C$. equisetifolia followed by $K$. senegalensis and $P$. pinnata resulted the highest values compared to other tree species. In respect of the accumulation of nickel (Ni) in the leaves, the highest values were obtained by $C$. equisetifolia and in the stem, the highest value in $K$. senegalensis, while G. arborea trees gave the highest values of nickel in the root. Concerning the accumulation of lead $(\mathrm{Pb})$ in the leaves, the highest values was noticed with $S$. mahagoni, while in the stem was in $K$. senegalensis, and in the root, the highest value was in $C$. equisetifolia and $S$. mahagoni. It can be concluded from the herein study that using treated waste water in irrigating woody trees was more effective and associated with increment of growth parameters sequence produceing healthy trees and enhanced both of specific gravity and fiber length. On the other hand, it is evident that cultivating timber trees irrigated by waste water can be used as phytoremidiation by absorbing the heavy metals such as $\mathrm{Ni}, \mathrm{Pb}$ and $\mathrm{Cd}$ which are not recommend in irrigation of the edible plants. It is possible to say that the trees under study can grow under the irrigation conditions of the treated waste water, and also expand their cultivation in the afforestation programs in Egypt for their environmental, economic and aesthetic importance, in particular the trees of Corymbia citriodora, Casuarina equisetifolia, Gmelina arborea, Khaya senegalensis, and Swietenia mahagoni .
\end{abstract}

Key words: timber trees, treated wastewater, growth measurements, specific gravity, fiber length, heavy metals.

\section{INTRODUCTION}

The use of treated and untreated waste water in irrigation for biomass production has several advantages besides the mitigation of pollution in the ecosystem (Juwarkar et al., 1995). Significant increase in growth performance in plant-height, branches, root length and the biomass were recorded in Casuarina equisetifolia saplings irrigated with untreated municipal raw sewage and treated sewage compared to that irrigated with unpolluted potable water over a period of 13 months (Kumar and Reddy, 2010).
In recent times, the danger of pollution of important water sources in Egypt, whether Nile water or groundwater, is highlighted by the increase in human activities, whether from industrial drainage or sewage. The safe and beneficial disposal of wastewater is to be used in irrigation and the establishment of important tree forests. The use of sewage water in the irrigation of trees is a common practice for many years. Woody trees reduce the environmental degradation of the soil because the trees are long-lived and can absorb and retain small elements of soil, water and air for a long time. 
Woody trees also create opportunities to produce biomass and the retention of excess minerals within the plant. Therefore, the use of waste water in irrigation of the artificial forests is a viable option for the economic disposal of wastewater.

The quality of the environment (such as water, air, and soil), micro-organism activities, plant growth, etc. is affected by heavy metal pollutants. Woody trees represent an excellent way to store minerals because of rapid growth, high biomass, widespread roots and little impact on human health (Patel et al., 2015).

The tree species differ in their ability to get rid of heavy metals. In this regard, a study (Yang et al., 2011) was conducted using 12 species of timber trees for the removal of heavy metals from the soil. Their study showed that juniper and poplar trees were the best for removal of copper, chromium and nickel. Prunus persica, Osmnthus fragrans and Sophora japonica trees were best to get rid of zinc, while Cedrus deodara trees were the best to get rid of cadmium and copper.

Azadirachta indica, famaily Meliaceae, is a small to medium-sized tree, usually evergreen, with a height of $15 \mathrm{~m}$ and a diameter of $90 \mathrm{~cm}$., Produces wood that can be manufactured but its fibers are rough and difficult to polish.

Casuarina equisetifolia L., family Casuarinaceae, is an evergreen tree with a height of $35 \mathrm{~m}$. Leaves consist of slender, muchbranched green to grey-green twigs $0.5-1 \mathrm{~mm}$ in diameter. The wood is used for shingles, fencing, and firewood (Masterson, 2009).

Corymbia citriodora (Hook.), family Myrtaceae, is a tall tree, reach to $35 \mathrm{~m}$ in height. It is also known as lemon eucalyptus and Eucalyptus citriodora. The volatile oil of the tree mainly consists of citronellal (80\%). Unrefined oil is used in perfumery and in insect repellents. It is an important forest tree used for structural timber and honey production (Atal and Kapur, 1982 and Rodriguez et al., 2015).

Gmelina arborea Roxb, family Verbenaceae, is a moderately sized to large deciduous tree with a straight trunk. The tree is wide spreading with numerous branches, attains to $30 \mathrm{~m}$ in height. The wood produces goodquality pulp, particle board, the manufacture of furniture, matches and timber for light construction (Roshetko et al., 2003).

Khaya senegalensis (Desr.), family, Meliaceae a half- deciduous tree, with a height of $15-30 \mathrm{~m}$ and a diameter of more than $1 \mathrm{~m}$.
The tree is resistant to flooding and can be cultivated in wetlands. The tree bears a wide range of soil conditions from neutral to acidic, from clay to sandy coarse soil. The tree produces one of the most important timber in terms of quality and is used on a commercial scale. The specific gravity of wood ranges from 0.60 to $0.85 \mathrm{gm} / \mathrm{cm}^{3}$ according to the site, its wood is resistant to fungus, insects and termites (Maydell, 1986).

Pongamia pinnata (L.) Pierre, family, Fabaceae a medium-sized tree that is evergreen or deciduous for a brief period, up to $15-25 \mathrm{~m}$ in height and 50-80 $\mathrm{cm}$ in diameter. The tree habitat is humid and subtropical environments. It is resistant to saline and alkaline conditions. Oil is the most important product of the tree and large quantities of seed are produced in India for industrial purposes (Daniel, 1997).

Swietenia mahagoni (L.) Jacq., family Meliaceae, is a long tree, up to $30 \mathrm{~m}$ height and up to $1 \mathrm{~m}$ in diameter, with abundant branches and gives a heavy shade. It is a deciduous tree in drought-prone areas. The heart wood is very resistant to decay and insect infestation, which makes it a favorite for other mahogany types in world markets. It produces the finest quality wood and introduces the best quality, cabinetwork, joinery, boats and pattern work (Orwa et al., 2009).

Tectona grandis L. family Verbenaceae, is a large deciduous tree with a height of $30 \mathrm{~m}$ in preferred growth conditions and a diameter of more than $1 \mathrm{~m}$. It produced a medium-weight timber, moderately soft and has a distinctive appearance. The heartwood is often light yellow at the beginning of the cut and then turns into a dark brown color. The wood has an oily texture and has a leather odor (Katende et al., 1995).

Therefore, the aim of the present work was to study the effect of irrigation with treated waste water on the growth characteristics and chemical components of the above-mentioned trees to determine the most suitable of these tree species and expand their cultivation on waste water in Egypt.

\section{MATERIAL AND METHODS}

The experiment was carried out at Serapium forest located in North Eastern of Egypt (C 302849.14 N - 321329.86 E) within the Governorate of Ismailia to define the best growth characteristics of certain timber trees irrigated with treated waste water. 


\subsection{Experimental Design}

One-year-old seedlings of Swietenia mahagoni, Tectona grandis, Gmelina arborea, Khaya senegalensis, Azadirachta indica, Corymbia citriodora, Pongamia pinnata and Casuarina equistifolia were planted in the field in 2015 season. Seedlings of all species were of the same age, were planted at $2.5 \times 2.5 \mathrm{~m}$ spacing and irrigated with dripp irrigation system; uniform tree seedlings for all inducted species were selected on the basis of height and stem diameter, ranged average $(30-40 \mathrm{~cm}$ for height and 0.5-0.6 $\mathrm{cm}$ for stem diameter). The experiment was carried out using a complete randomized design where each species contains three replicates and each replicate contains 12 plants.

\subsection{Growth measurements}

The total height $(\mathrm{m})$, diameter at $50 \%$ of total height $(\mathrm{cm})$ at the first year from planting and diameter at breast height $(\mathrm{DBH})(\mathrm{cm})$ at second and third year, number of branches and survival $\%$ of each tree species were measured at one, two and three years from planting (2016, 2017 and 2018). At the end of the experiment, leaves sample was dried and ground to pass through a $1 \mathrm{~mm}$ sieve for analyses of $\mathrm{N}, \mathrm{P}$ and $\mathrm{K}$. Nitrogen $(\mathrm{N} \%)$ was determined using the Kjeldahl method. Potassium (K \%) was determined by flame photometry, while Phosphorus (P \%) was determined by using colorimetric determination according to the methods described by (Cottenie et al. 1982). Moreover, heavy metals (ppm) $\mathrm{Cd}, \mathrm{Pb}$ and $\mathrm{Ni}$ in roots, leaves and stems were determined by atomic absorption spectrophotometer after acidifying with nitric acid according to (Brandifeld and Spincer, 1965).

\subsection{Specific gravity and fiber length determinations}

For determination of specific gravity $\left(\mathrm{gm} / \mathrm{cm}^{3}\right)$ a disc was cut from each tree, then a small specimen was cut from each disk at dimensions of $2 \times 2 \times 2 \mathrm{~cm}^{3}$; specific gravity was recorded as a green volume by displacement in water and oven-dry weight method. Meanwhile, wood samples of fiber length $(\mathrm{mm})$ measurements were taken; specimens were prepared and measured as mentioned by Franklin (1945).

\subsection{Soil and water analysis}

Soil chemical properties were determined before and after the experiment; soil samples were randomly collected from two depths (0-30 and $30-60 \mathrm{~cm}$ ) by digging profiles and analyzed according to Page et al. (1982) as shown in Table (1). The chemical characteristics of treated wastewater as shown in Table (2) were analyzed by using the methodology described in APHA, (1998).

\subsection{Statistical analysis}

Data were statistically analyzed and means were performed by the new L.S.D. test at 5\% level as described by Snedecor and Cochran (1980).

Table (1): Chemical analysis of the soil before and after using of treated waste water for the tested tree species.

\begin{tabular}{|c|c|c|c|c|}
\hline \multirow{3}{*}{$\begin{array}{c}\text { Soil } \\
\text { Properties }\end{array}$} & \multicolumn{2}{|c|}{$\begin{array}{l}\text { Before } \\
\text { planting }\end{array}$} & \multicolumn{2}{|c|}{ After planting } \\
\hline & \multicolumn{4}{|c|}{ Depth } \\
\hline & $\begin{array}{l}\mathbf{0 - 3 0} \\
(\mathbf{c m})\end{array}$ & $\begin{array}{c}30-60 \\
(\mathrm{~cm})\end{array}$ & $\begin{array}{l}0-30 \\
(\mathbf{c m})\end{array}$ & $\begin{array}{c}30-60 \\
(\mathrm{~cm})\end{array}$ \\
\hline $\mathrm{pH}$ & 7.00 & 7.03 & 7.03 & 7.03 \\
\hline S.P.\% & 21.00 & 20.30 & 22.30 & 22.50 \\
\hline $\mathrm{EC}(\mathrm{dS} / \mathrm{m})$ & 1.07 & 1.74 & 3.07 & 1.08 \\
\hline \multicolumn{5}{|c|}{ Soluble anions (meg/l) } \\
\hline $\mathrm{CO}_{3}$ & - & - & - & - \\
\hline $\mathrm{HCO}_{3}$ & 2.35 & 1.20 & 8.82 & 2.35 \\
\hline $\mathrm{Cl}$ & 1.79 & 3.58 & 9.84 & 2.68 \\
\hline $\mathrm{SO} 4$ & 5.26 & 10.30 & 11.00 & 5.00 \\
\hline \multicolumn{5}{|c|}{ Soluble cations (meq/l) } \\
\hline $\mathrm{Ca}$ & 2.46 & 3.69 & 4.30 & 1.84 \\
\hline $\mathrm{Mg}$ & 1.46 & 0.23 & 3.05 & 1.10 \\
\hline $\mathrm{Na}$ & 4.76 & 10.63 & 20.50 & 6.75 \\
\hline $\mathrm{K}$ & 0.72 & 0.53 & 1.81 & 0.34 \\
\hline
\end{tabular}

Table (2):Chemical analysis of the treated waste water used for irrigation in the current study.

\begin{tabular}{|c|l|c|}
\hline No. & \multicolumn{1}{|c|}{ Parameter } & Value \\
\hline $\mathbf{1}$ & $\mathrm{TSS}\left(\mathrm{mg} \mathrm{l}^{-1}\right)$ & 28.6 \\
\hline $\mathbf{2}$ & $\mathrm{pH}$ & 7.68 \\
\hline $\mathbf{3}$ & $\mathrm{TDS}\left(\mathrm{mg} \mathrm{l}^{-1}\right)$ & 620 \\
\hline $\mathbf{4}$ & ${\mathrm{BOD}\left(\mathrm{mg} \mathrm{l}^{-1}\right)}_{1}$ & 48.3 \\
\hline $\mathbf{5}$ & $\mathrm{NH}_{4}-{\mathrm{N}\left(\mathrm{mg} \mathrm{l}^{-1}\right)}_{1}$ & 23.6 \\
\hline $\mathbf{6}$ & ${\mathrm{Total} \mathrm{P}\left(\mathrm{mg} \mathrm{l}^{-1}\right)}_{2.89}$ \\
\hline $\mathbf{7}$ & $\mathrm{EC}\left(\mathrm{dsm}^{-1}\right)$ & 1.63 \\
\hline $\mathbf{8}$ & $\mathrm{Pb}(\mathrm{ppm})$ & 1.03 \\
\hline $\mathbf{9}$ & $\mathrm{Ni}(\mathrm{ppm})$ & 0.05 \\
\hline $\mathbf{1 0}$ & $\mathrm{Cd}(\mathrm{ppm})$ & 0.07 \\
\hline $\mathbf{1 1}$ & $\mathrm{Cr}(\mathrm{ppm})$ & 0.09 \\
\hline
\end{tabular}




\section{RESULTS AND DISCUSSION}

3.1. Effect of irrigation with waste water on the growth of seedlings at the age of 1 , 2 and 3 years from establishment

Table (3) shows the effect of irrigation using treated wastewater on the growth characteristics of the studied tree species during three years of cultivation. There were significant differences between tree species in total height, stem diameter, number of branches and survival percentage of trees. C. citriodora, $C$. equisetifolia, $G$. arborea trees were the most common tree species in response to irrigation with treated waste water, where the results indicated that significant increases in height and diameter were obtained compared with the other trees species after one, two or three years from planting.

Data in Table (3) indicated that the total height of $C$. citriodora significantly increased $(2.32,7.13$ and $8.97 \mathrm{~m})$ after one, two and three years from planting, respectively, as compared with the other tree species, followed by $C$. equisetifolia, $G$. arborea trees. While $P$. pinnata was the lowest in total height $(0.75,1.54$ and $2.01 \mathrm{~m}$, respectively) after one, two and three years from planting, as compared with the other tree species.
Concerning the stem diameter, data in Table (3) show significant differences among tree species. G. arborea and C. citriodora recorded the highest value of root collar diameter $(3.31$ and $3.24 \mathrm{~cm})$ after one year from planting as compared with the other tree species, and $C$. citriodora gave the highest diameter at breast height $(6.53$ and $8.00 \mathrm{~cm})$ after two and three years after planting, respectively. While $A$ indica and $S$. mahagoni gave the lowest values in root collar diameter $(1.53$ and $1.66 \mathrm{~cm})$ after one year from planting. On the other side, the lowest value of diameter at breast height was in $P$. pinnata and S.mahagoni $(1.11$ and $1.39 \mathrm{~cm})$ after two years from planting,but were 2.20 and $2.39 \mathrm{~cm}$, after three year from planting respectively.

As regard to branches number, data presented in Table (3) illustrated that the highest number of branches exhibited in $K$. sengalensis tree (4.24 branches/ plant) after three years from planting as compared with other tree species. While the lowest values were in $C$. citriodora, S.mahagoni and C. equisetifolia (1.77, 2.04 and 2.11 branches/ plant respectively), after three years from planting. However, the highest percentage of survival were recorded with $C$. citriodora, A.indica and G. arborea (97.29,

Table (3): Effect of irrigation with treated waste water on the growth characteristics after one, two and three years from establishment of certain tree seedlings (2016, 2017 and 2018 seasons ).

\begin{tabular}{|c|c|c|c|c|c|c|c|c|c|c|c|c|}
\hline \multirow{3}{*}{ Tree species } & \multirow{2}{*}{\multicolumn{3}{|c|}{ Total height (m) }} & \multicolumn{3}{|c|}{ Stem diameter(cm) } & \multirow{2}{*}{\multicolumn{3}{|c|}{$\begin{array}{c}\text { Branches } \\
\text { number/tree }\end{array}$}} & \multirow{2}{*}{\multicolumn{3}{|c|}{ Survival \% }} \\
\hline & & & & \multirow{2}{*}{\begin{tabular}{|c|c|c|}
$\begin{array}{c}\text { Root } \\
\text { collar } \\
\text { diameter }\end{array}$ \\
$\mathbf{1}^{s t}$ \\
\end{tabular}} & \multicolumn{2}{|c|}{$\begin{array}{l}\text { Diameter at } \\
\text { breast height } \\
\text { (DBH) }\end{array}$} & & & & & & \\
\hline & $1^{s t}$ & $2^{n d}$ & $3^{\text {th }}$ & & $2^{\text {nd }}$ & $3^{\text {th }}$ & $1^{s t}$ & $2^{\text {nd }}$ & $3^{\text {th }}$ & $\mathbf{1}^{s t}$ & $2^{\text {nd }}$ & $3^{\text {th }}$ \\
\hline $\begin{array}{l}\text { Khaya } \\
\text { senegalensis }\end{array}$ & 0.72 & 1.63 & 2.62 & 2.60 & 1.91 & 3.07 & 1.33 & 2.76 & 4.24 & 81.67 & 79.17 & 72.92 \\
\hline $\begin{array}{l}\text { Swietenia } \\
\text { mahagoni }\end{array}$ & 0.76 & 1.75 & 2.51 & 1.66 & 1.39 & 2.39 & 0.67 & 1.47 & 2.04 & 81.76 & 79.17 & 72.08 \\
\hline Azadirachta indica & 0.93 & 2.73 & 3.62 & 1.53 & 2.17 & 3.49 & 1.33 & 2.79 & 2.87 & 94.00 & 93.75 & 93.75 \\
\hline Tectona grandis & 0.79 & 2.08 & 2.55 & 2.06 & 1.95 & 2.69 & 1.00 & 2.31 & 2.68 & 78.33 & 77.08 & 67.71 \\
\hline Pongamia pinnata & 0.75 & 1.54 & 2.01 & 2.12 & 1.11 & 2.20 & 1.33 & 2.51 & 2.57 & 88.33 & 85.42 & 75.00 \\
\hline $\begin{array}{l}\text { Casuarina } \\
\text { equisetifolia }\end{array}$ & 1.64 & 3.40 & 4.82 & 2.22 & 2.44 & 4.06 & 0.67 & 1.85 & 2.11 & 91.67 & 89.58 & 87.50 \\
\hline Gmelina arborea & 1.21 & 3.39 & 4.22 & 3.31 & 3.51 & 5.48 & 1.00 & 2.19 & 2.26 & 94.33 & 93.75 & 92.50 \\
\hline $\begin{array}{l}\text { Corymbia } \\
\text { citriodora }\end{array}$ & 2.32 & 7.13 & 8.97 & 3.24 & 6.53 & 8.00 & 0.67 & 1.63 & 1.77 & 98.00 & 97.92 & 97.29 \\
\hline New L.S.D at (0.05) & 0.10 & 0.21 & 0.31 & 0.40 & 0.35 & 0.46 & 0.60 & 0.24 & 0.35 & 5.54 & 5.02 & 5.44 \\
\hline
\end{tabular}


93.75 and $92.50 \%$ respectively) after three years from planting, as compared with other tree species. While, the lowest percentage of survival was in $T$. grandis $(78.33,77.08$ and $67.71 \%$ ) after one, two and three years from planting, respectively, as compared with other tree species.

Growth parameters of eight tree species were evaluated for selecting the trees that can withstand irrigation by using treated wastewater and can be cultivated as man made forests. For C. citriodora, C. equistifolia and G. arborea trees, treated with waste water had a positive effect on height and diameter compared to that of the other species. However, for the number of branches, the highest number was observed from $K$. senegalensis and $A$. indica trees, while $C$. citriodora, $A$.indica and $G$. arborea trees were the highest percentage of survival. It can be said that some tree species had the most ability to grow and to withstand the conditions of irrigation with treated waste water (Cornelissen et al. 1997; Adrover et al., 2008 and Ghorab et al., 2017).

\subsection{Effect of irrigation with wastewater on} the specific gravity and fiber length

It is obvious from data in Table (4) that, the highest mean values of specific gravity for the tested woody trees as response to irrigation with wastewater was resulted in $C$. citriodora $(0.58$ $\left.\mathrm{g} / \mathrm{cm}^{3}\right), \quad P$. pinnata $\left(0.57 \mathrm{~g} / \mathrm{cm}^{3}\right)$ and $C$. equisetifolia $\left(0.54 \mathrm{~g} / \mathrm{cm}^{3}\right)$, while the lowest values were obtained by $A$. indica and $T$. grandis $\left(0.42 \mathrm{~g} / \mathrm{cm}^{3}\right)$. Also, the same Table pointed out that, maximum fiber length $(1.11,1.09$ and $1.08 \mathrm{~mm}$ ) were recorded in $C$. equisetifolia, $K$.

Table (4): Effect of irrigation with treated wastewater on specific gravity $(\mathrm{g} / \mathrm{cm} 3)$ and fiber length $(\mathrm{mm})$ of wood three years from establishment of certain tree seedlings.

\begin{tabular}{|l|l|l|}
\hline \multicolumn{1}{|c|}{ Tree species } & $\begin{array}{c}\text { Specific } \\
\text { gravity } \\
\left(\mathrm{g} / \mathbf{c m}^{\mathbf{3}}\right)\end{array}$ & $\begin{array}{c}\text { Fiber } \\
\text { length } \\
(\mathbf{m m})\end{array}$ \\
\hline Khaya sengalensis & $\mathbf{0 . 4 7}$ & 1.09 \\
\hline Swietenia mahagoni & $\mathbf{0 . 5 0}$ & $\mathbf{0 . 6 9}$ \\
\hline Azadirachta indica & $\mathbf{0 . 4 2}$ & $\mathbf{0 . 8 4}$ \\
\hline Tectona grandis & $\mathbf{0 . 4 2}$ & $\mathbf{0 . 9 6}$ \\
\hline Pongamia pinnata & $\mathbf{0 . 5 7}$ & 1.08 \\
\hline Casuarina equisetifolia & $\mathbf{0 . 5 4}$ & $\mathbf{1 . 1 1}$ \\
\hline Gmelina arborea & $\mathbf{0 . 4 5}$ & $\mathbf{0 . 8 2}$ \\
\hline Corymbia citriodora & $\mathbf{0 . 5 8}$ & 1.01 \\
\hline
\end{tabular}

sengalensis and $P$. pinnata, under treated wastewater irrigation, respectively, while minimum fiber length were obtained in $S$. mahagoni $(0.69 \mathrm{~mm})$ and $G$. arborea $(0.82 \mathrm{~mm})$.

Although high- density is preferred where high- strength lumber products are required, it must be recognized that density varies considerably within a given species (Paul, 1963). Fiber length influences were much more important in manufacture the pulp where the paper properties such as tearing resistance is related to fiber length. Pulp and paper properties, including tear resistance and tensile, fold and burst strength. In most cases, long lengths are desirable, Maeglin et al. (1977). No significant differences were observed for the specific gravity and fiber length of wood produced from seedlings irrigated by primary treated waste water compared with well water (Al-Mefarrej, 2013). Specific gravity of Leucaena leucocephala seedlings was not affected by waste water irrigation (Klem, 1968), however, waste water at $50 \%$ concentration increased fiber length of those seedlings (Hassan and Ali, 2013).

\subsection{Effect of irrigation with wastewater on} the leaves contents of $N, P$ and $K$

Data in Table (5) indicated the leaves content of $\mathrm{N}, \mathrm{P}$ and $\mathrm{K}$ for 8 tested trees as response to irrigation with treated wastewater. There were differences among tree species. The highest mean values of nitrogen content were recorded with $G$. arborea, $C$. citriodora and $C$. equistifolia trees $(2.82,2.69$ and $2.54 \%$, respectively). Meanwhile, the lowest values of nitrogen were resulted from $P$. pinnata and $T$. grandis (1.33 and $1.60 \%$, respectively). The leaves of $C$. equistifolia and C. citriodora

Table (5): Effect of irrigation with treated wastewater on nitrogen, phosphorus and potassium (\%) in leaves three years from establishment of certain tree seedlings.

\begin{tabular}{|l|l|l|l|}
\hline \multicolumn{1}{|c|}{ Tree species } & N \% & P\% & K\% \\
\hline Khaya sengalensis & 2.02 & $\mathbf{0 . 2 5}$ & 1.16 \\
\hline Swietenia mahagoni & 1.86 & $\mathbf{0 . 2 7}$ & 1.20 \\
\hline Azadirachta indica & 2.39 & $\mathbf{0 . 3 5}$ & 1.14 \\
\hline Tectona grandis & 1.60 & $\mathbf{0 . 2 0}$ & $\mathbf{0 . 7 7}$ \\
\hline Pongamia pinnata & 1.33 & $\mathbf{0 . 2 2}$ & $\mathbf{0 . 9 7}$ \\
\hline Casuarina equisetifolia & $\mathbf{2 . 5 4}$ & $\mathbf{0 . 5 2}$ & $\mathbf{0 . 8 2}$ \\
\hline Gmelina arborea & $\mathbf{2 . 8 2}$ & $\mathbf{0 . 3 7}$ & 1.35 \\
\hline Corymbia citriodora & $\mathbf{2 . 6 9}$ & $\mathbf{0 . 5 0}$ & $\mathbf{1 . 2 5}$ \\
\hline
\end{tabular}


contained higher phosphorus than that of all the other species ( 0.52 and $0.50 \%$ respectively). While, $T$. grandis and $P$. pinnata trees produced the lowest values $(0.20$ and $0.22 \%$, respectively). The content of $\mathrm{K}$ in $G$. arborea and $C$. citriodora leaves were more than that of the other species( 1.35 and $1.25 \%$, respectively). While, T.grandis and $C$. equistifolia resulted in the lowest value of $\mathrm{K}$ content in their leaves $(0.77$ and $0.82 \%$, respectively).

Some of the species, such as G. arborea, $C$. citriodora and $C$. equisetifolia trees, contained more nitrogen compared to the other species, while $C$. equisetifolia and $C$. citriodora were greater in phosphorus than all the other species. $\mathrm{K}$ content in G. arborea and C. citriodora leaves was more than that of the other species. Mineral content was differed among species in leaves, stems, and roots. Nitrogen content in leaves was higher in deciduous than in evergreen species (Cornelissen et al., 1997). However, the choice of tree species based on growth and absorption of elements is important for the purification of treated waste water by the tree plantations (Hooda, 2007). Quantity of nutrients absorbed by plants depends on its quantity in the treated waste water, soil qualities and plant species (Bozkurt and Yarilga, 2003).

3.4. Effect of irrigation with wastewater on $\mathrm{Ni}, \mathrm{Pb}$ and $\mathrm{Cd}$ (ppm) accumulation:

Regarding the heavey metal contents in leaves (Table 6) C. equistifolia, A. indica and $S$. mahagoni trees under treated waste water irrigation contained the highest values of nickel (Ni ppm) contents, $(0.87,0.84$ and $0.77 \mathrm{ppm}$,

Table (6): Effect of irrigation with treated waste water on the heavy metals accumulation in leaves three years from establishment of certain tree seedlings (ppm).

\begin{tabular}{|l|c|c|c|}
\hline \multicolumn{1}{|c|}{ Tree species } & $\mathrm{Ni}$ & $\mathrm{Pb}$ & $\mathrm{Cd}$ \\
\hline Khaya sengalensis & $\mathbf{0 . 7 5}$ & 4.32 & $\mathbf{0 . 2 3}$ \\
\hline Swietenia mahagoni & $\mathbf{0 . 7 7}$ & 4.74 & $\mathbf{0 . 2 7}$ \\
\hline Azadirachta indica & $\mathbf{0 . 8 4}$ & 3.34 & $\mathbf{0 . 2 4}$ \\
\hline Tectona grandis & $\mathbf{0 . 4 3}$ & 2.42 & $\mathbf{0 . 1 1}$ \\
\hline Pongamia pinnata & $\mathbf{0 . 5 1}$ & 2.64 & $\mathbf{0 . 1 2}$ \\
\hline Casuarina equisetifolia & $\mathbf{0 . 8 7}$ & 3.08 & $\mathbf{0 . 2 3}$ \\
\hline Gmelina arborea & $\mathbf{0 . 7 1}$ & 2.76 & $\mathbf{0 . 2 0}$ \\
\hline Corymbia citriodora & $\mathbf{0 . 7 6}$ & 4.25 & $\mathbf{0 . 2 4}$ \\
\hline
\end{tabular}

respectively), while minimum contents were obtained in $T$. grandis and $P$. pinnata $(0.43$ and $0.51 \mathrm{ppm}$, respectively) in their leaves. Mean values showed that $S$. mahagoni, $K$. sengalensis and $C$. citriodora with irrigation by treated wastewater contained maximum lead contents (4.74, 4.32 and $4.25 \mathrm{ppm}$, respectively). Meanwhile, T. grandis and $P$. pinnata leaves contained the lowest values of lead (2.42 and $2.64 \mathrm{ppm}$, respectively). Three years from establishment, the highest values of cadmium were recorded in S. mahogani, A. indica and $C$. citriodora $(0.27,0.24$ and 0.24 ppm, respectively). While the minimum values were obtained in $T$. grandis and $P$. pinnata leaves (0.11 and $0.12 \mathrm{ppm}$, respectively).

Mean values of $\mathrm{Ni}, \mathrm{Pb}$ and $\mathrm{Cd}$ accumulation in stem regarding the tested tree species showed that, $K$. sengalensis and $P$. pinnata contained the highest and the lowest values, respectively (Table 7). Also, in the same Table the values of the heavy metals accumulated in the tree stems can be arranged in descending order as follows: lead followed by nickel and cadmium. Maximum nickel (Ni ppm) content was recorded in $K$. sengalensis, $C$. equisetifolia and $G$. arborea $(1.15,0.93$ and $0.89 \mathrm{ppm}$, respectively), while the lowest values were recorded in $P$. pinnata $(0.53 \mathrm{ppm})$. Maximum lead $(\mathrm{Pb} \mathrm{ppm})$ contents were recorded in $K$. sengalensis, C. citriodora and G. arborea (6.14, 4.47 and $3.84 \mathrm{ppm}$, respectively). While minimum contents were obtained in $P$. pinnata and C. equisetifolia $(2.90$ and $2.95 \mathrm{ppm}$, respectively). However, mean values of cadmium $(\mathrm{Cd} \mathrm{ppm})$ in stem revealed that $K$. sengalensis and $G$. arborea attained the highest

Table (7): Effect of irrigation with treated waste water on the heavy metals accumulation in stem three years from establishment of certain tree seedlings (ppm).

\begin{tabular}{|l|c|c|c|}
\hline \multicolumn{1}{|c|}{ Tree species } & $\mathrm{Ni}$ & $\mathrm{Pb}$ & $\mathrm{Cd}$ \\
\hline Khaya sengalensis & 1.15 & 6.14 & $\mathbf{0 . 4 1}$ \\
\hline Swietenia mahagoni & $\mathbf{0 . 6 3}$ & 3.48 & 0.19 \\
\hline Azadirachta indica & 0.86 & 3.69 & 0.25 \\
\hline Tectona grandis & $\mathbf{0 . 5 8}$ & 3.76 & $\mathbf{0 . 1 7}$ \\
\hline Pongamia pinnata & $\mathbf{0 . 5 3}$ & 2.90 & $\mathbf{0 . 1 6}$ \\
\hline Casuarina equisetifolia & $\mathbf{0 . 9 3}$ & 2.95 & 0.22 \\
\hline Gmelina arborea & $\mathbf{0 . 8 9}$ & 3.84 & 0.27 \\
\hline Corymbia citriodora & $\mathbf{0 . 8 4}$ & 4.47 & 0.22 \\
\hline
\end{tabular}


contents (0.41 and $0.27 \mathrm{ppm}$, respectively). While $P$. pinnata and $T$. grandis contained the lowest one ( 0.16 and $0.17 \mathrm{ppm}$, respectively).

It is clear from data in Table (8) that, $G$. arborea, A. indica and $S$. mahagoni trees contained maximum nickel $(\mathrm{Ni})$ in their roots $(0.95,0.92$ and $0.81 \mathrm{ppm}$, respectively) as compared to the other species, while $T$. grandis and $P$. pinnata contained minimum values $(0.60$ and $0.64 \mathrm{ppm}$, respectively). C. equisetifolia, $S$. mahogani and $K$. sengalensis trees contained the highest values of lead $(\mathrm{Pb})$ in their $\operatorname{roots}(4.64$, 4.14 and $4.03 \mathrm{ppm}$, respectively) after three years from establishment compared to the other species, while $P$. pinnata and $T$. grandis containe the lowest one (2.90 and $2.96 \mathrm{ppm}$, respectively). The maximum values of cadmium contents in the roots were recorded in A. indica, G. arborea and $S$. mahagoni $(0.26,0.26$ and $0.24 \mathrm{ppm}$, respectively). While the minimum values were found in $T$. grandis and $P$. pinnata trees $(0.15$ and $0.17 \mathrm{ppm}$, respectively). The potential of using irrigation with treated wastewater for increasing biomass production in forest is considerable (Sopper and Kerr, 1979). However heavy metals absorption was affected by tree species, tree age and its concentrations in the soil. The potential problems that have been recognized in connection with the disposal of using sewage effluent for agricultural lands are the accumulation of heavy metals in the soil and plants (Elsokkary and El-Keiy, 1988). However, these problems depend mainly on the composition of the sewage, frequency of application, soil properties and plant species (Verma et al., 1999). Alloway (1995) revealed that heavy metals are more mobile at acid

Table (8): Effect of irrigation with treated waste water on the heavy metals accumulation in roots three years from establishment of certain tree seedlings (ppm).

\begin{tabular}{|l|c|c|c|}
\hline \multicolumn{1}{|c|}{ Tree species } & $\mathrm{Ni}$ & $\mathrm{Pb}$ & $\mathrm{Cd}$ \\
\hline Khaya sengalensis & $\mathbf{0 . 7 1}$ & 4.03 & $\mathbf{0 . 2 1}$ \\
\hline Swietenia mahagoni & $\mathbf{0 . 8 1}$ & 4.14 & $\mathbf{0 . 2 4}$ \\
\hline Azadirachta indica & $\mathbf{0 . 9 2}$ & $\mathbf{3 . 8 4}$ & $\mathbf{0 . 2 6}$ \\
\hline Tectona grandis & $\mathbf{0 . 6 0}$ & 2.96 & $\mathbf{0 . 1 5}$ \\
\hline Pongamia pinnata & $\mathbf{0 . 6 4}$ & 2.90 & $\mathbf{0 . 1 7}$ \\
\hline Casuarina equisetifolia & $\mathbf{0 . 7 3}$ & 4.64 & $\mathbf{0 . 2 2}$ \\
\hline Gmelina arborea & $\mathbf{0 . 9 5}$ & 3.60 & $\mathbf{0 . 2 6}$ \\
\hline Corymbia citriodora & $\mathbf{0 . 7 9}$ & 3.97 & $\mathbf{0 . 2 3}$ \\
\hline
\end{tabular}

conditions and the increasing of $\mathrm{pH}$ by liming reduced their bioavailability. Also, Waly et al. (1987) reported that available and total heavy metals in soils showed significantly correlation with the organic matter in the soil. Planting timber trees species is very important to utilization of wastewater and for phytoremediation of heavy metals in short period of time if heavy metals can be control from different industries. Also the results showed that Cupressus sempervirens trees gave the highest translocation factor (TF) of $\mathrm{Zn}$ and $\mathrm{Cd}$ from root to stem and Eucalyptus camaldulensis trees were increased significantly with (TF) from root to stem of $\mathrm{Mn}$ and $\mathrm{Ni}$ as compared with Corymbia citriodora and Pinus halepensis (Ghorab et al., 2012).

\section{Conclusion}

Through this study, it can be concluded that, such important tree species can be cultivated under irrigation conditions by using treated waste water and expanded it in the different afforestation programs in Egypt because of their adaptability to the Egyptian environmental conditions, biomass production, phytoremediation, economic and aesthetic importance, especially C. citriodora, $C$. equisetifolia, G. arborea, $K$. senegalensis and $S$. mahagoni trees.

\section{REFERENCES}

Adrover M., Forss A.L., Ramon G., Vadell J., Moya G. and Taberner A. M. (2008). Selection of woody species for wastewater enhancement and restoration of riparian woodlands. J. Environ. Biol., 29(3): 357361.

Alloway B. J. (1995). Heavy Metals in Soils. Chapman \& Hall, London, UK., 368 p.

Al-Mefarrej H.A. (2013). Growth characteristics and some wood quality of Tamarix aphylla seedlings irrigated with primary treated wastewater under drought stress. Asian J. Plant Sci., 12 (3 ):109-118.

APHA (1998). American Public Health Association, Standard Methods for the Examination of Water and Waste water. $20^{\text {th }}$ ed. Washington, DC, USA.

Atal C.K. and Kapur B.M. (1982). Cultivation and Utilization of Medicinal Plants. Regional Research Laboratory. Jammu Tawi, India, 877 p. 
Bozkurt M.A. and Yarilga T. (2003). The Effects of sewage sludge applications on the yield, growth, nutrition and heavy metal accumulation in apple trees growing in dry conditions. Turk. J. Agric. For., 27: 285292.

Brandifeld E.G. and Spincer D. (1965). Determination of magnesium, calcium, zinc and copper by atomic absorption spectroscopy. J. Food. Agric. Sci., 16:3338.

Cornelissen J.H.C., Werger M.J.A. , Castro-Diez P. Van Rheenen J.W.A. and Rowland A.P. (1997). Foliar nutrients in relation to growth, allocation and leaf traits in seedlings of a wide range of woody plant species and types. Oecologia, 111(4):460469.

Cottenie A., Verloo M., Kiekens L., Velghe G. and Camerlynck R. (1982). Chemical Analysis of Plant and Soil. Laboratory of Analytical and Agrochemistry, State Univ., Ghent, Belgium, 1982p.

Daniel J.N. (1997). Pongamia pinnata - A nitrogen fixing tree for oilseed. A Publication of the Forest, Farm, and Community Tree Network (FACT Net). Winrock International Pp.1-4.

Elsokkary I.H. and El- Keiy O.M. (1988). Effect of sewage sludge application on the growth and heavy metals content of five plant crops grown on calcareous soil. Proceedings of the $3^{\text {rd }}$ Inter. Conf. on Environ. Contamin., September, 26- 29, Venice, pp 170-173, Italy.

Franklin G.L. (1945). Preparation of thin selection of synthetic resins and wood-resin composites, and a new macerating method for wood. Nature, 155( 1): 51-57.

Ghorab S. A. S., Ismail M. F. M. and Khaliel H. M. K. (2012). Phytoremediation of heavy metals by four hyper accumulation timber tree species irrigated with treated waste water (2) Translocation, bioconcentration and enrichment factors of heavey metals in tree parts and soil. Egypt. J. Appl. Sci., 27 (2): $71-88$.

Ghorab S. A. S., Ismail M. F. M. and Abd ElLah S.A. (2017). Growth rate, basal area and volume of Corymbia citriodora and Cupressus sempervirens irrigated with treated wastewater at Serabium Forest. Egypt. J. Agric. Res., 95 (3): 1145- 1157.

Hassan F. A. and Ali H. M. (2013). Impact of irrigation with sewage effluent on the growth and wood properties of two forest tree seedlings. J. Forest Prod. \& Indus., 2(2): 40-44.

Hooda V. (2007). Phytoremediation of toxic metals from soil and waste water. J. Environ. Biol., 28: 367-376.

Juwarkar A.S., Thawale P.R., Juwarkar A.A. and Khanna P. (1995). A case study of environmental problems in the use of wastewater for crop irrigation. National workshop on health, agriculture and environmental aspects of waste water use: UNEP- WHO- NEERI.

Katende A. B., Birnie A. and Tengnas B. (1995). Useful trees and shrubs for Uganda. Identification, Propagation and Management for Agricultural and Pastoral Communities. Regional Soil Conservation Unit (RSCU), Swedish International Development Authority, (SIDA) pp. 729.

Klem G.S. (1968). Quality of wood from fertilized forests. Tappi., 50(11): 99- 103.

Kumar A.Y. and Reddy M.V. (2010). Effects of municipal sewage on the growth performance of Casuarina equisetifolia on sandy soil of East Coast at Kalpakkam (Tamil Nadu, India). Appl. Ecol. and Environ.1 Res., 8(1): 77-85.

Maeglin R.R., Hallock H., Freeze F. and McDonald K.A. (1977). Effect of nitrogen fertilization on black walnut growth, low quality, and wood anatomy. USDA Forest Service Res. Pap. FPL- 294,13p.

Masterson J. (2009). Casuarina equistifolia (Asturalian Pine). Fort Pierce: Smithsonian Marine Station. Retriveds May 2009. https://en.wikipedia.org/wiki/Casuarina_eq uisetifolia

Maydell H.J. (1986). Trees and shrubs of the Sahel - their characteristics and uses. GTZ $6 \mathrm{MBH}$, Eschborn, 525p.

Orwa C., Mutua A., Kindt R., Jamnadass R. and Anthony S. (2009). Agroforestry Database: A tree reference and selection guide version 4.0

(http://www.worldagroforestry.org/sites/tre edbs/treedatabases.asp).

Page A.L., Miller R. H. and Keeney D.R. (1982). Methods of Soil Analysis. Part 2 American Society of Agronomy, Madison, W.l. USA. 1159 PP.

Patel K. S., Sharma R., Dahariya N.S., Yadav A., Blazhev B., Matini L. and Hoinkis J. (2015). Heavy metal contamination of tree leaves. Amer. J. Analytical Chem., 6: 
687- 693

Paul B.H. (1963).The application of silviculture in controlling the specific gravity of wood. US Dep. Agric. Forest. Service Tech. Bull., No. 1288, 97.

Rodriguez S.D., Drake L.L., Price D.P., Hammond J.I. and Hansen I.A. (2015). The Efficacy of some commercially available insect repellents for Aedes aegypti (Diptera:Culicidae) and Aedes albopictus (Diptera:Culicidae).J.Insect Sci.,15(1):140144. https://doi.org/10.1093/jisesa/iev125.

Roshetko J.M., Mulawarman J.M.R. and Purnomosidhi P. (2003). Gmelina arborea Available species for small holder tree farming in Indonesia: Recent Advances with Gmelina arborea. New forest., 28(2): 207-215.

Snedecor G.W. and Cochran W.G. (1980). Statistical Methods. $7^{\text {th }}$, the lowa State Univ.Press. Ames., lowe., U.S.A.,PP.593.
Sopper W.E. and Kerr S.N. (1979). Utilization of municipal sewage effluent and sludge on forest and disturbed land. Pennsylvania Univ. Press, Univ. Park, PA., USA.

Waly T. M., Omran M. S., Abd Elnaim E.M. and El-Nashar B.M.B. (1987). Effect of sewage water on chemical properties and heavy metals content of El-Gabal El-Asfar sandy soils. Biol. wastes, 22(4) 275-284.

Verma Y., Hargen M.C., Ruperelia S.G. and Kulkami P.K. (1999). Toxicity testing of tannery effluents using duckweed (Lemna minor) bioassay. Pollut. Res., 18 (4): 497500.

Yang J., Yao D., Li X. and Zhang Z. (2011). Research on Effect of Woody Plants Remediation Heavy Metal. In: D. Jin and S. Lin (Eds.): CSISE, AISC, Advances in Computer Science, Intelligent System and Environment. Springer, Berlin, Heidelberg, Germany 106: 679-684. 


\section{دراسة نمو بعض أنواع الأشجار الخشبية المحلية والمستوردة المروية بمياه الصرف الصحي المعالج مجدي اسماعيل بهنسي \\ قسم بحوث الأشجار الخشبية والغابات ـمعهد بحوث البساتين - مركز البحوث الزر اعية ـ الجيزه - مصر}

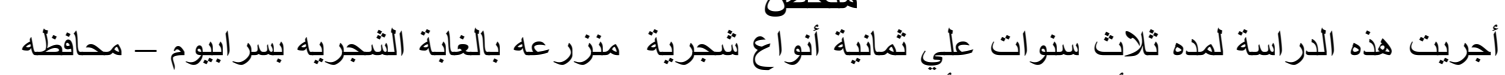

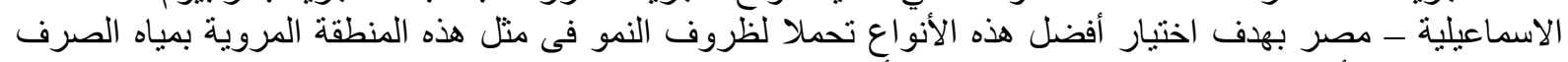

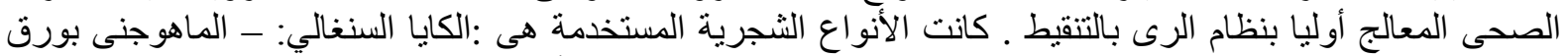

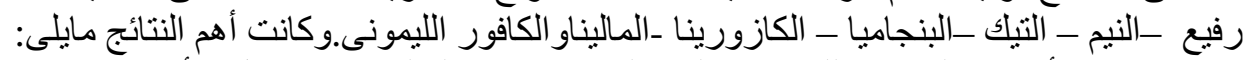

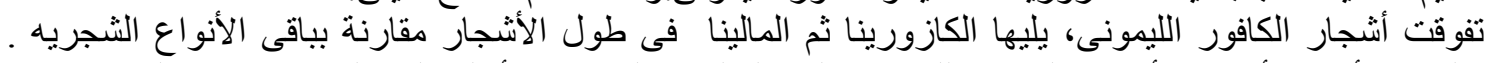

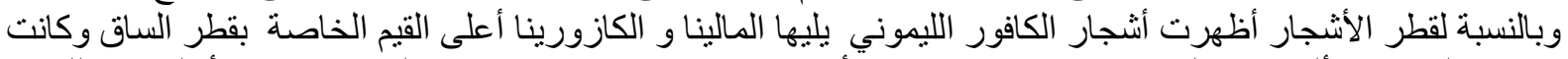

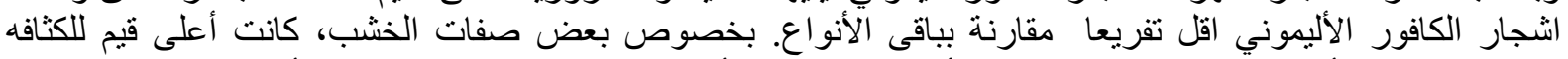

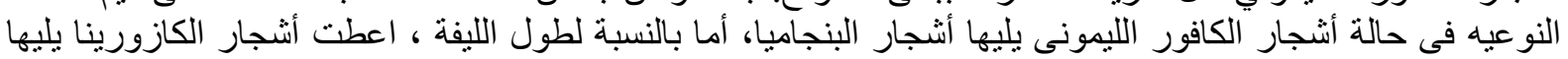

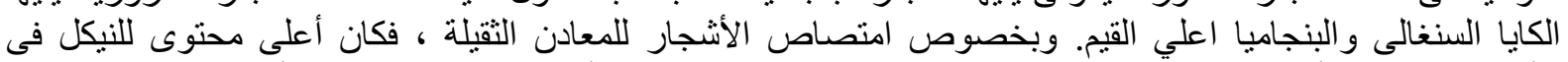

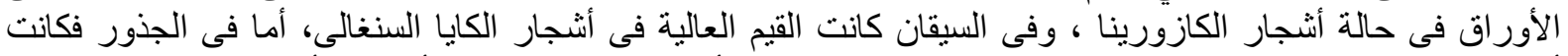

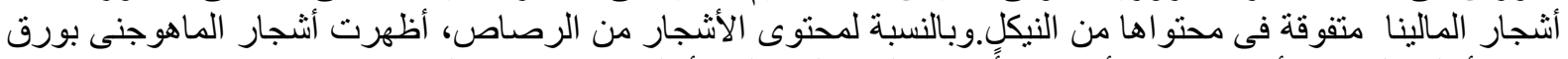

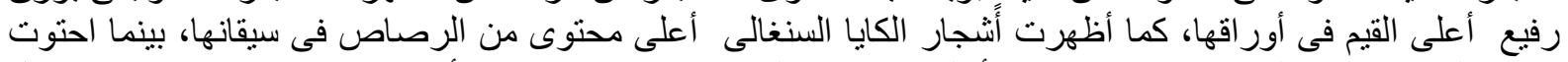

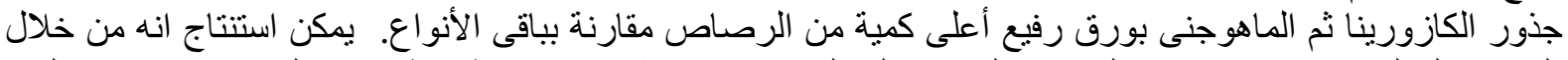

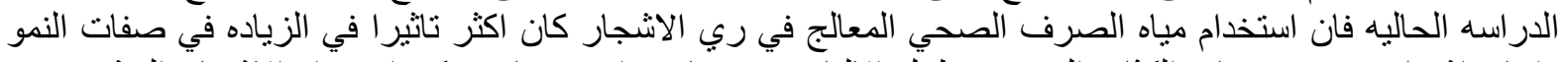

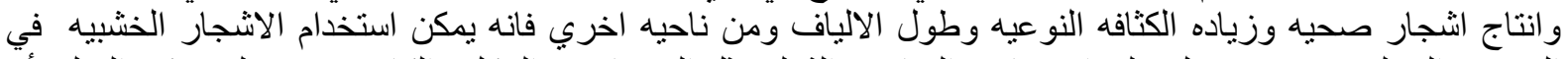

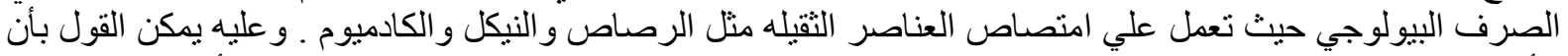

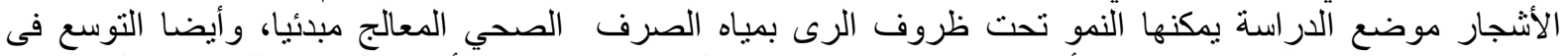

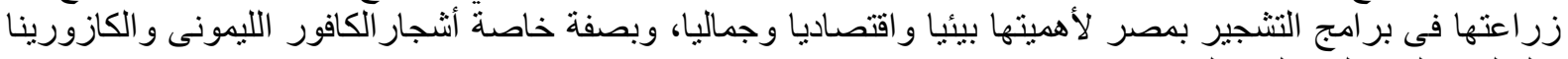

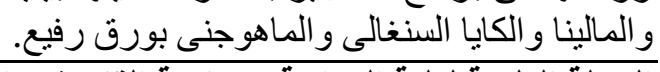

